Original article

https://www.journal-imab-bg.org

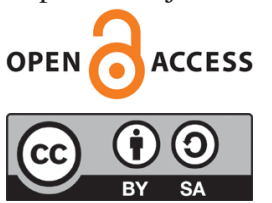

\title{
GLUTEN-SENSITIVE ENTEROPATHY - A POTENTIALLY CURABLE CAUSE OF HEPATIC DISORDERS
}

\author{
Lili Grudeva \\ Clinic of Gastroenterology, Hepatology and Nutrition, Department of Internal \\ Diseases, Medical University of Varna, Bulgaria.
}

\begin{abstract}
Introduction: The clinical spectrum of gluten-sensitive enteropathy is remarkably varied and the disease can affect many extraintestinal organs and systems, including the liver. Liver involvement, which is observed in patients with gluten-sensitive enteropathy, varies from an asymptomatic increase of hepatic enzymes or non-specific reactive hepatitis (cryptogenic hepatic disorders) to chronic liver disease. The histological changes and the dynamics of enzymes are notably different after a glutenfree diet (GFD) treatment.

Patients and Methods: A clinical observation included 112 patients with gluten-sensitive enteropathy and 22 patients with gluten sensitivity, who passed through the Clinic of Gastroenterology, Hepatology and Nutrition at St. Marina University Hospital, Varna for the period from January, 2005 to June, 2015. Thirty-four men and 78 women between the ages of 18 and 76 were included. The control group consisted of 22 patients of whom 6 were men and 16 - women.
\end{abstract}

Results and Discussion: Patients with proven hepatic diseases with autoimmune or viral genesis were excluded from the group participating in the current study. The observation and study were conducted on 8 patients - 3 men and 5 women put on a GFD for a period of 6 months. All 8 patients were with abnormal hepatic enzyme levels. The median levels $( \pm \mathrm{SD})$ of ASAT and ALAT were $62.6 \pm 16.5 \mathrm{IU} / \mathrm{mL}$ with a range of 31-186 IU/mL, and 69.3 $\pm 9.3 \mathrm{IU} / \mathrm{mL}$ and a range of $63-432 \mathrm{IU} / \mathrm{mL}$, respectively. The median concentrations of alkaline phosphatase were $\pm 280.3 \pm 118.7 \mathrm{mmol} / \mathrm{L}$ (range $-160-428 \mathrm{mmol} / \mathrm{L}$ ).

Six months after GFD, the hepatic enzyme levels decreased to a level of $24.5 \pm 5.1 \mathrm{IU} / \mathrm{mL}$ in all patients. Hepatic abnormalities varying from mild changes of hepatic enzyme levels to liver failure at the time of diagnosis could be treated with GFD. Its effect on the severity of other hepatic diseases, for example autoimmune hepatitis, is not clear yet. Regardless of the effect on the concomitant hepatic diseases, GFD is needed for the improvement of the symptoms of gluten-sensitive enteropathy and all long-term consequences. The lack of sufficient amount of proof does not undermine the fact that clinicians should consider the diagnosis - gluten-sensitive enteropathy - when hypertransaminasemia is observed without the presence of other causes of liver dysfunction.

Keywords: gluten-sensitive enteropathy (GE), hypertransaminasemia, gluten-free diet (GFD)

\section{INTRODUCTION}

Gluten-sensitive enteropathy (GE) is an autoimmune disease of the digestive system in which an abnormal reaction to gluten [1] is developed - the protein fraction in wheat, rye, barley, and to a lesser degree - in oats. The condition is one of the most widely spread gastrointestinal disorders with a large spectrum of clinical manifestations [2].

The exact cause of the liver damage in patients with GE has not been studied well yet [3].

However, it is known that hypertransaminasemia can be an initial manifestation of GE [4]. There are numerous hepatic diseases, which can be related to it [5].

\section{Hepatic Diseases Related to GE}

- Isolated hypertransaminasemia with parenchymal damage, reversible with a gluten-free diet (GFD) (celiac hepatitis) [6]

- Cryptogenic cirrhosis

- Autoimmune hepatic disorders

- Primary biliary cirrhosis

- Autoimmune hepatitis

- Autoimmune cholangitis

- Primary sclerosing cholangitis

- Chronic viral infection

- Hemochromatosis

- Non-alcoholic fatty liver disease [7]

- Acute liver failure

- Regenerative nodular hyperplasia

- Hepatocellular carcinoma [8]

\section{PATIENTS AND METHODS}

A clinical observation included 112 patients with gluten-sensitive enteropathy and 22 patients with gluten sensitivity, who passed through the Clinic of Gastroenterology, Hepatology and Nutrition at St. Marina University Hospital, Varna for the period from January, 2005 to 
June, 2015. Thirty-four men and 78 women between the ages of 18 and 76 were included. The control group consisted of 22 patients of whom 6 were men and $16-$ women.

\section{RESULTS AND DISCUSSION}

All patients from the studied group underwent routine laboratory biochemical testing - AST (normal range - 0.0-34 IU/mL), ALT (normal range - 10-35 IU/mL), alkaline phosphatase (ALP) (normal range - 45-1292 U/mL), bilirubin - 5.0-21 mmol/L. The levels above the upper limit of the range were considered proof of liver failure. Patients with proven hepatic diseases with autoimmune or viral genesis were excluded from the group in the current study. Monitoring and testing was conducted on 8 patients -3 men and 5 women with altered hepatic function. All patients were put on GFD.

Before the start of the study a detailed medical history was taken, including past diseases, medicament intake, foods with possible toxic effect, and alcohol intake. An ultrasound study of the hepatobiliary system was conducted.

The mean age of the studied patients was 26.4 4.8 years (range 19-32 years). All of them underwent an endoscopic study and a morphologic diagnosis was established using the Marsh-Oberhuber classification.
The distribution was as follows: Marsh 2 - 1, Marsh3a - 3, Marsh3b - 3, Marsh3c - 1. No IgA deficit was established in any of the patients. At the start of the study only one of the female patients had increased levels of total bilirubin, and the rest had normal initial levels with a mean level of $10.5 \pm 0.5$ (range 7-30).

All 8 patients had abnormal hepatic enzyme levels. The mean ASAT and ALAT levels $( \pm$ SD) were $62.6 \pm$ $16.5 \mathrm{IU} / \mathrm{mL}(\mathrm{range}-31-186 \mathrm{IU} / \mathrm{mL})$ and $69.3 \pm 9.3 \mathrm{IU} / \mathrm{mL}$ (range 63-432IU/mL), respectively. The mean alkaline phosphatase concentration $( \pm \mathrm{SD}$ ) was $280.3 \pm 118.7 \mathrm{mmol} /$ L (range $-160-428 \mathrm{mmol} / \mathrm{L}$ ).

After a six-month course of GFD, the hepatic enzyme levels decreased to normal values in all patients $24.5 \pm 5.1 \mathrm{IU} / \mathrm{mL}$ and $18-37 \mathrm{IU} / \mathrm{mL}$ in women (p - 0.04 ); and $28.6 \pm 6 \mathrm{IU} / \mathrm{mL}$ and $22-33 \mathrm{IU} / \mathrm{mL}$ in men, although no statistically significant differences were established (p-0.33). The alkaline phosphatase concentration decreased to $180.3 \pm 50.6 \mathrm{mmol} / \mathrm{L}$ (range $180-280 \mathrm{mmol} / \mathrm{L}$ ), 6 months after GFD. The differences from the pre-GFD levels had no statistical significance (p-0.09). The predominant reactive hepatitis in this cohort $-7 \%$, had complete resolution after GFD.

Table 1 presents the serum levels of bilirubin, AST, ALT, and ALP, before and after GFD.

Table 1. Results from the hepatic enzyme tests before and after GFD

\begin{tabular}{|c|c|c|c|c|c|c|c|c|c|c|}
\hline \multirow[b]{2}{*}{ Patients } & \multirow[b]{2}{*}{ Age } & \multirow[b]{2}{*}{ Gender } & \multicolumn{2}{|c|}{ Total Bilirubin } & \multicolumn{2}{|c|}{ AST (IU/mL) } & \multicolumn{2}{|c|}{ ALT (IU/mL) } & \multicolumn{2}{|c|}{$\mathrm{ALP}(\mathrm{mmol} / \mathrm{L})$} \\
\hline & & & $\begin{array}{c}\text { Before } \\
\text { GFD }\end{array}$ & $\begin{array}{l}\text { After } \\
\text { GFD }\end{array}$ & $\begin{array}{c}\text { Before } \\
\text { GFD }\end{array}$ & $\begin{array}{l}\text { After } \\
\text { GFD }\end{array}$ & $\begin{array}{c}\text { Before } \\
\text { GFD }\end{array}$ & $\begin{array}{l}\text { After } \\
\text { GFD }\end{array}$ & $\begin{array}{c}\text { Before } \\
\text { GFD }\end{array}$ & $\begin{array}{l}\text { After } \\
\text { GFD }\end{array}$ \\
\hline 1 & 21 & $\mathrm{M}$ & 8 & 7 & 66 & 24 & 81 & 31 & 243 & 219 \\
\hline 2 & 19 & M & 11 & 9 & 48 & 30 & 76 & 23 & 160 & 148 \\
\hline 3 & 29 & M & 10 & 9 & 31 & 22 & 72 & 27 & 260 & 216 \\
\hline 4 & 24 & F & 7 & 8 & 55 & 21 & 63 & 26 & 328 & 210 \\
\hline 5 & 33 & $\mathrm{~F}$ & 11 & 9 & 68 & 37 & 108 & 33 & 330 & 220 \\
\hline 6 & 27 & $\mathrm{~F}$ & 11 & 7 & 55 & 31 & 87 & 30 & 321 & 280 \\
\hline 7 & 34 & $\mathrm{~F}$ & 30 & 20 & 186 & 31 & 432 & 33 & 428 & 180 \\
\hline 8 & 30 & $\mathrm{~F}$ & 11 & 10 & 58 & 18 & 73 & 22 & 298 & 186 \\
\hline
\end{tabular}

Several studies report percentages that are a little higher - for example Disky et al. [9] report $15 \%$ hypertransaminasemia among the newly diagnosed patients with GE. Abdo et al. [10] report 9\% hypertransaminasemia. It is possible that this not-so-striking difference from our study is due to the fact that the Bulgarian population might consume larger quantities of alcohol and have a higher incidence of steatohepatitis compared to the other populations.

One of the cases was of particular interest. A young woman presented at the clinic with a severe form of malabsorption syndrome, acute reactive hepatitis (all possibilities for an underlying hepatic disease were excluded). In her case, after timely diagnosis and diet therapy, full resolution of the symptoms and biochemical indicators was observed, starting as early as the third month.

\section{CONCLUSION}

Liver abnormalities varying from hepatic enzyme level changes to liver failure at the time of GE diagnosis can be treated with GFD [9]. Its influence of the severity of the rest of the hepatic diseases, such as autoimmune hepatitis, is still not clear. Regardless of its effect on the concomitant hepatic disorders, GFD is necessary for the improvement of GE symptoms and all long-term consequences [7]. The lack of enough proof does not undermine the fact that clinicians should consider GE as a diagnosis in the presence of hypertransaminasemia and a lack of other causes of liver failure $[11,12]$. We think that 
the most probable cause of elevated hepatic enzyme levels is reactive hepatitis presenting with the main disease.

Despite the accumulation of significant scientific proof in the last decades, future studies are still needed in order to establish the GE incidence in the different hepatic [6] diseases and to prove the possible link between them. An early diagnosis and GFD therapy might lead to slowing down or stopping the progress of the hepatic disease.

\section{REFERENCES:}

1. Majumdar K, Sakhuja P, Puri AS, Gaur K, Haider A, Gondal R. Coeliac disease and the liver: spectrum of liver histology, serology and treatment response at a tertiary referral centre. $J$ Clin Pathol. 2018; 71(5):412-9. [PubMed] [CrossRef]

2. Newnham ED, Shepherd SJ, Strauss BJ, Hosking P, Gibson PR. Adherence to the gluten-free diet can achieve the therapeutic goals in almost all patients with coeliac disease: A 5-year longitudinal study from diagnosis. J Gastroenterol Hepatol. 2016; 31(2):342-9.[PubMed] [CrossRef]

3. Casswall TH, Papadogiannakis $\mathrm{N}$, Ghazi S, Németh A. Severe liver damage associated with celiac disease: Findings in six toddler-aged girls. Eur J Gastroenterol Hepatol. 2009; 21(4): 452-9. [PubMed] [CrossRef]

4. Korpimäki S, Kaukinen K, Collin P, Haapala AM, Holm P, Laurila K, et al. Gluten-sensitive hypertransaminasemia in celiac disease: An infrequent and often subclinical finding. Am J Gastroenterol. 2011; 106(9):168996.[PubMed] [CrossRef]

5. Maggiore G, Caprai S. The liver in celiac disease. J Pediatr Gastroenterol Nutr. 2003; 37(2):117-9. [PubMed]

6. Dickey W, McMillan SA, Collins JS, Watson RG, McLoughlin JC, Love AH. Liver abnormalities associated with celiac sprue. How common are they, what is their significance, and what do we do about them? J Clin Gastroenterol. 1995; 20(4):2902. [PubMed]

7. Abenavoli L, Milic N, De Lorenzo A, Luzza F. A pathogenetic link between non-alcoholic fatty liver disease and celiac disease. Endocrine. 2013; 43(1):65-7. [PubMed] [CrossRef]

8. Rubio-Tapia A, Murray JA. The liver in celiac disease. Hepatology. 2007; 46(5):1650-8. [PubMed] [CrossRef]
9. Dickey W, McMillan SA, Collins JS, Watson RG, McLoughlin JC, Love AH. Liver abnormalities associated with celiac sprue. How common are they, what is their significance, and what do we do about them? J Clin Gastroenterol. 1995; 20(4):290-2. [PubMed]

10. Abdo A, Meddings J, Swain M. Liver Abnormalities in celiac disease. Clin Gastroenterol Hepatol. 2004; 2(2):107-12. [PubMed]

11. Volta U, De Franceschi L, Lari F, Molinaro N, Zoli M, Bianchi FB. Coeliac disease hidden by cryptogenic hypertransaminasaemia. Lancet. 1998; 352(9121):26-9. [PubMed] [CrossRef]

12. Kaukinen K, Halme L, Collin P, Färkkilä M, Mäki M, Vehmanen $\mathrm{P}$, et al. Celiac disease in patients with severe liver disease: Gluten-free diet may reverse hepatic failure. Gastroenterology. 2002;122(4):881-8. [PubMed] [CrossRef]

Please cite this article as: Grudeva L. Gluten-Sensitive Enteropathy - a Potentially Curable Cause of Hepatic Disorders. J of IMAB. 2019 Jul-Sep;25(3):2692-2694. DOI: https://doi.org/10.5272/jimab.2019253.2692

Received: 23/01/2019; Published online: 09/09/2019
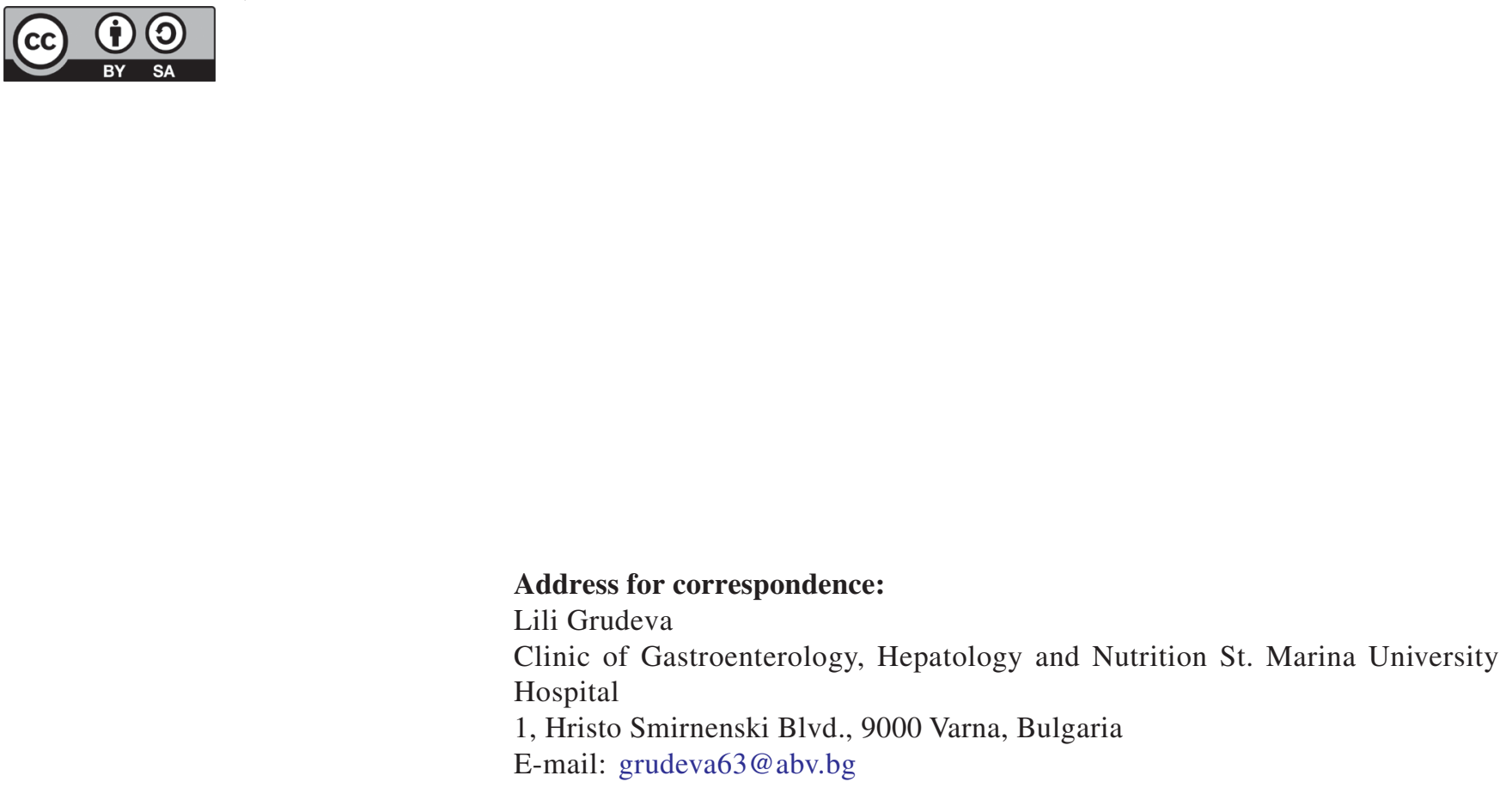